\title{
MEMPERSIAPKAN GENERASI EMAS INDONESIA TAHUN 2045 MELALUI PENDIDIKAN BERKUALITAS
}

\author{
Regina Ade Darman \\ Dosen Pendidikan Informatika, STKIP PGRI Sumbar \\ Email: reginaade1986@gmail.com
}

Submitted: 16-03-2017, Reviewed: 17 -03- 2017, Accepted 18-03-2017

http://dx.doi.org/10.22202/jei.2017.v3i2.1320

\begin{abstract}
Abstrak
Pendidikan merupakan sebuah proses untuk membentuk manusia yang tidak hanya cerdas secara intelektual, mampu berpikir secara saintifik dan filosofis tetapi juga mampu mengembangkan spiritualnya. Pendidikan tanpa guru, ibarat ruangan tanpa cahaya. Guru memiliki peran yang sangat strategis bagi dunia pendidikan, karena dari semua komponen pendidikan yang ada seperti kurikulum, sarana prasarana, metode pembelajaran, guru, siswa, orang tua, dan lingkungan, yang paling menentukan adalah guru. Guru memiliki kedudukan yang sangat mulia, dari merekalah tercipta generasi emas Indonesia. Tantangan pendidikan berkualitas, mengharuskan guru untuk lebih kreatif, inovatif, dan inspiratif dalam mendesain kegiatan pembelajaran yang bermutu untuk menyongsong generasi emas Indonesia Tahun 2045. Guru menjadi kunci utama keberhasilan sumber daya manusia yang tidak hanya produktif tetapi juga unggul dan religious. Sehubungan dengan itu, tidak terlepas dari upaya pemerintah untuk bersinergi mencerdaskan anak bangsa. Peran pendidikan dalam mempersiapkan generasi 2045 sangat penting. Target yang dicanangkan pemerintah berupa munculnya generasi emas Indonesia dalam sepuluh atau dua puluh tahun kedepan yaitu dengan meluaskan kesempatan akses pendidikan lebih tinggi. Selain itu, dengan meningkatkan kualitas pendidikan sejalan dengan upaya meningkatkan kompetensi dan kesejahteraan guru. Untuk mempersiapkan generasi emas Indonesia 2045, penting bagi dunia pendidikan melakukan perubahan pola pikir. Pendidikan tidak sekadar dimaknai dengan transfer akademik (keilmuan) saja, melainkan dilengkapi dengan karakter. Keseimbangan akademik dan karakter inilah yang perlu disiapkan sejak sekarang. Pemerintah selalu menuntut guru untuk bisa lebih kreatif, inovatif dan inspiratif dalam mendesain kegiatan pembelajaran yang bermutu untuk menyongsong generasi emas Indonesia. Jika memang guru menjadi kunci utama, seharusnya pemerintah meletakkan kekuasaan penuh terhadap guru untuk menyusun kurikulum serta mengevaluasi. Untuk mencapai generasi emas Indonesia maka diperlukan juga Usaha meningkatkan mutu pendidikan di Indonesia seperti : (1) Meningkatkan Anggaran Pendidikan, (2) Manajemen pengelolaan pendidikan, (3) Bebaskan sekolah dari suasana bisnis, (4) Perbaikan kurikulum, (5) Pendidikan Agama, (6) Pendidikan yang melatih kesadaran kritis, (7) Pemberdayaan Guru.
\end{abstract}

Kata Kunci : Generasi emas Indonesia

\section{Pendahuluan}

Pendidikan adalah proses perkembangan kecakapan seseorang dalam bentuk sikap dan prilaku yang berlaku dalam masyarakatnya. Proses sosial dimana seseorang dipengaruhi oleh sesuatu lingkungan yang terpimpin (khususnya di sekolah) sehingga iya dapat mencapai kecakapan sosial dan mengembangkan kepribadiannya. Pendidikan merupakan sebuah proses untuk membentuk manusia yang tidak hanya cerdas secara intelektual, mampu berpikir secara saintifik dan filosofis tetapi juga mampu mengembangkan spiritualnya.

\section{Diterbitkan Oleh Program Studi Pendidikan Informatika STKIP PGRI Sumbar}


Pendidikan tanpa guru, ibarat ruangan tanpa cahaya. Guru memiliki peran yang sangat strategis bagi dunia pendidikan, karena dari semua komponen pendidikan yang ada seperti kurikulum, sarana prasarana, metode pembelajaran, guru, siswa, orang tua, dan lingkungan, yang paling menentukan adalah guru. Guru memiliki kedudukan yang sangat mulia, dari merekalah tercipta generasi emas Indonesia. Terlebih guru mengemban amanat untuk mewujudkan pendidikan nasional yaitu berkembangnya potensi peserta didik agar menjadi manusia yang beriman dan bertaqwa kepada Tuhan Yang Maha Esa, berakhlak mulia, berilmu, cakap, kreatif, mandiri, serta menjadi warga Negara yang demokratis dan bertanggung jawab.

Indonesia akan menuju kebangkitan kedua, yaitu 100 tahun Indonesia merdeka pada tahun 2045. Inilah yang melatarbelakangi kebangkitan generasi emas. Inilah saat yang tepat bagi pendidikan untuk berperan menciptakan generasi emas Indonesia. Ini adalah momentum sangat tepat bagi para pemangku kepentingan pendidikan untuk menata dengan sebaik-baiknya pendidikan berkualitas.

Tantangan pendidikan berkualitas, mengharuskan guru untuk lebih kreatif, inovatif, dan inspiratif dalam mendesain kegiatan pembelajaran yang bermutu untuk menyongsong generasi emas Indonesia Tahun 2045. Guru menjadi kunci utama keberhasilan sumber daya manusia yang tidak hanya produktif tetapi juga unggul dan religious. Sehubungan dengan itu, tidak terlepas dari upaya pemerintah untuk bersinergi mencerdaskan anak bangsa.

Pada masa sekarang, pendidikan di Indonesia merujuk pada UUD 1945 Pasal 31 dan UU No 23 tahun 2003 tentang Sistem Pendidikan Nasional. Salah satu prinsip gerakan reformasi dalam pendidikan adalah pendidikan diselenggarakan dengan memberdayakan semua komponen masyarakat melalui peran serta mereka dalam penyelenggaraan dan pengendalian mutu pendidikan. Namun saat ini, Sistem pendidikan di Indonesia terlalu memaksa anak untuk dapat menguasai sekian banyak bidang studi dengan materi yang sedemikian abstrak, yang selanjutnya membuat anak merasa tertekan/stress yang dampaknya membuat mereka suka bolos, bosan sekolah, tawuran, mencontek, dan lain-lain. Pada akhirnya mereka tidak dapat mengerjakan ujian dengan baik, nilai mereka kurang padahal sudah dilakukan remidi, dan supaya dianggap bisa mengajar atau karena tidak boleh ada nilai kurang atau karena kasihan beban pelajaran siswa terlalu banyak, kemudian guru melakukan manipulasi nilai raport. Nilai raport inilah yang kemudian dijadikan dasar untuk memperoleh beasiswa atau melanjutkan kuliah atau ikut PMDK dan lain sebagainya.

Tidak hanya manipulasi raport yang ada dalam pendidikan Indonesia, bahkan ada fakta yang mengejutkan yaitu, "Tragedi Ujian Nasional" yang membuat bangsa ini merasa risau dan khawatir akan kelangsungan pendidikan berkualitas yang sudah digadanggadang dan dijanjikan pemerintah. Fakta membuktikan dana besar yang dikeluarkan tidak sesuai dengan kenyataan yang ada yaitu mulai dari tidak konsistennya Pemerintah dalam menentukan jadwal UN 2013 untuk jenjang SMA/MA, dengan adanya perbedaan jadwal untuk wilayah Indonesia lainnya. Kemudian distribusi soal yang buruk serta kertas soal dan LJUN yang sangat tipis dan mudah rusak, dan masih banyak lagi fakta-fakta lainnya.Faktafakta ini membuat penulis bertanya-tanya, apakah UN ini dapat dijadikan sebagai pemetaan kualitas pendidikan untuk mempersiapkan generasi emas Indonesia.

Berdasarkan laporan Education for All Global Monitoring Report yang dirilis UNESCO 2011, tingginya angka putus sekolah menyebabkan peringkat indeks pembangunan rendah. Indonesia berada di peringkat 69 dari 127 negara dalam Education Development Index. Sementara, laporan Departeman Pendidikan dan Kebudayaan, setiap menit ada empat anak yang putus sekolah. Perkembangan pendidikan Indonesia masih tertinggal bila dibandingkan dengan negara-negara berkembang lainnya. Menurut Education For All Global Monitoring Report 2011 yang dikeluarkan oleh UNESCO setiap tahun dan

\section{Diterbitkan Oleh Program Studi Pendidikan Informatika STKIP PGRI Sumbar}


berisi hasil pemantauan pendidikan dunia, dari 127 negara, Education Development Index (EDI) Indonesia berada pada posisi ke-69, dibandingkan Malaysia (65) dan Brunei (34).

Sehubungan dengan itu, penulis sangat tertarik mengangkat masalah-masalah pendidikan tersebut yang penulis tuangkan dalam sebuah karya ilmiah yang berjudul "Mempersiapkan Generasi Emas Indonesia Tahun 2045 Melalui Pendidikan Berkualitas"

\section{I.2 Rumusan Masalah}

Secara khusus, permasalahan yang akan dibahas dalam penelitian ini dapat di rumuskan sebagai berikut :

1. Apakah Pendidikan itu?

2. Apakah yang dimaksud dengan Pendidikan Emas Indonesia?

3. Apa keterkaitan antara pendidikan dengan generasi emas Indonesia?

4. Bagaimana cara mencapai generasi emas indonesia?

5. Manfaat generasi emas Indonesia bagi kehidupan bangsa dan Negara?

\section{I.3 Tujuan}

Berdasarkan rumusan masalah diatas, secara umum karya ilmiah ini bertujuan untuk mengetahui sejauh mana perkembangan pendidikan di Indonesia. Secara khusus, karya ilmiah ini bertujuan untuk :

1. Masalah apa yang terdapat dalam perkembangan tersebut dan menjelaskan penyebabnya

2. Melalui karya ilmiah diharapkan bisa mengatasi masalah yang terjadi sehingga dapat memajukan pendidikan di Indonesia

\section{I.4 Manfaat}

Karya ilmiah ini diharapkan dapat bermanfaat oleh berbagai pihak. Secara teoritis, karya ilmiah ini diharapkan dapat memberikan acuan untuk meningkatkan pendidikan Indonesia. Secara praktis, karya ilmiah ini diharapkan dapat bermanfaat, terutama :
1. Bagi penulis, menambah wawasan dan pengetahuan dalam pencapaian pendidikan generasi emas Indonesia.

2. Bagi pembaca, dapat dijadikan sebagai bahan pertimbangan untuk pendidikan masa sekarang dan masa yang akan datang. sehingga dapat mencari solusinya secara bersama agar pendidikan di masa yang akan dapat meningkat baik dari segi kualitas maupun kuantitas yang diberikan.

\section{I.5 Metode Studi Pustaka}

Segala usaha yang dilakukan oleh penulis untuk menyimpan informasi yang relevan dengan topik.

\section{TELAAH PUSTAKA \\ II. 1. Pengertian Pendidikan}

Sebelum kita membahas mengenai persiapan pendidikan menuju generasi emas Indonesia, sebaiknya kita melihat definisi dari pendidikan itu terlebih dahulu. Menurut Kamus Besar Bahasa Indonesia, pendidikan berasal dari kata dasar didik (mendidik), yaitu memelihara dan memberi latihan (ajaran, pimpinan) mengenai akhlak dan kecerdasan pikiran. Sedangkan pendidikan mempunyai pengertian yaitu proses pengubahan sikap dan tata laku seseorang atau kelompok orang dalam usaha mendewasakan manusia melalui upaya pengajaran dan latihan, proses perbuatan, cara mendidik.

Beberapa ahli yang mendefinisikan pendidikan, salah satunya adalah menurut John Dewey, pendidikan adalah proses tanpa akhir (education in the process without end). Dan pendidikan merupakan proses pembentukan kemampuan dasar yang fundamental, baik menyangkut daya piker (daya intelektual) maupun daya emosional (perasaan) yang diarahkan kepada tabiat manusia dan kepada sesamanya.

Ditinjau dari sudut hukum, definisi pendidikan berdasarkan Undang-Undang RI Nomor 20 Tahun 2003 tentang Sisdiknas, Pasal 1 ayat (1) dalam artikel Hikmawati (20130, bahwa "pendidikan adalah suatu usaha sadar dan terencana untuk mewujudkan suasana belajar dan proses pembelajran agar peserta 
didik secara aktif mengembangkan potensi dirinya untuk memiliki kekkuatan spiritual keagamaan, pengendalian diri, kepribadian, kecerdasan, akhalak mulia, serta keterampilan yang diperlukan dirinya, masyarakat, bangsa, dan Negara".

Berangkat dari definisi pendidikan yang telah dijabarkan pada paragraf di atas, dapat dipahami bahwa pendidikan merupakan proses yang terus menerus, tidak berhenti. Di dalam proses pendidikan ini, keluhuran martabat manusia dipegang erat karena manusia (yang terlibat dalam pendidikan ini) adalah subyek dari pendidikan.

Karena merupakan subyek di dalam pendidikan, maka dituntut suatu tanggung jawab agar tercapai suatu hasil pendidikan yang baik. Jika memperhatikan bahwa manusia itu sebagai subyek dan pendidikan meletakkan hakikat manusia pada hal yang terpenting, maka perlu diperhatikan juga masalah otonomi pribadi. Maksudnya adalah, manusia sebagai subyek pendidikan harus bebas untuk "ada" sebagai dirinya yaitu manusia yang berpribadi, yang bertanggung jawab.

\section{II.2. Generasi Emas Indonesia}

Setelah membahas apa itu pendidikan maka kita juga harus membahas tentang generasi emas Indonesia. Tahun 2012 hingga 2035 adalah masa menanam generasi emas indonesia. Oleh karenanya, dalam kurun waktu tersebut pemerintah dan segenap masyarakat terus menggalakkan program pendidikan. Munculnya harapan besar ini didukung potensi sumber daya manusia Indonesia. Tahun 20102035 Indonesia memasuki periode bonus demografi, di mana usia produktif paling tinggi di antara usia anak-anak dan orang tua. Mengapa periode 2010-2035 sebagai periode bonusi demografi? tentunya kita melirik dari report Badan Pusat Statistik (BPS) tahun 2010 dimana jumlah penduduk Indonesia usia muda lebih banyak dibandingkan dengan usia tua. Dalam data itu terlihat, jumlah anak kelompok usia 0-9 tahun sebanyak 45,93 juta, sedangkan anak usia 10-19 tahun berjumlah 43,55 juta jiwa. Di Proyeksi pada tahun 2045, mereka yang usia 0-9 tahun akan berusia 35-45 tahun, sedangkan yang usia 10-20 tahun berusia 45-54.

Tentunya pada periode tahun 2010 sampai tahun 2035 kita harus melakukan investasi besar-besaran dalam bidang pengembangan sumber daya manusia (SDM) sebagai upaya menyiapkan generasi 2045, yaitu 100 tahun Indonesia merdeka. Oleh karena itu, kita harus menyiapkan akses seluas-luasnya kepada seluruh anak bangsa untuk memasuki dunia pendidikan; mulai dari pendidikan anak usia dini (PAUD) sampai ke perguruan tinggi. Tentu perluasan akses tersebut harus diikuti dengan peningkatan kualitas pendidikan, sekalipun kita semua memahami bahwa pendidikan itu adalah sistem rekayasa sosial terbaik untuk meningkatkan kesejahteraan, keharkatan dan kemartabatan.

Sistem pendidikan masa depan bangsa Indonesia adalah pendidikan yang mengantarkan generasi masa kini menjadi generasi emas Indonesia 2045. Tepat pada tahun 2045 Indonesia 100 tahun terlepas dari belenggu penjajah. Ditahun tersebut Indonesia mengharap memiliki gold generation yang dapat membangun bangsa kearah yang lebih baik. Menurut Ketua Asosiasi Lembaga Pendidikan dan Tenaga Kependidikan Indonesia (ALPTKI) Prof. Dr. Sunaryo Kartadinata, M.Pd. saat menyampaikan makalah utama dalam Konperensi Nasional Pendidikan Indonesia (Konaspi)VII yang diselenggarakan Universitas Negeri Yogyakarta, di Royal Ambarrukmo, Yogyakarta, Kamis (1/11/2012), "Generasi ini akan menjadi generasi penduduk warga dunia yang bersifat transkultural, namun harus tetap hidup dan berkembang dalam jati diri dan budaya Indonesia sebagai sebuah bangsa yang bermartabat".

Menurut Rektor Universitas Pendidikan Indonesia ini, daya saing di satu sisi dan kemampuan kolaborasi di sisi lain adalah dua polar kompetensi yang harus bersinergi sebagai profil dasar manusia Indonesia 2045. Gambaran sosok manusia Indonesia generasi 2045 harus menjadi pijakan dan cantolan upaya pendidikan, dan pendidikan akan memainkan peran baru 
dalam perspektif pengembangan sosok generasi 2045.

Beberapa uraian pada halaman sebelumnya mengenai generasi emas Indonesia, dapat disimpulkan bahwa di Tahun 2045 nanti, tepat Indonesia berusia 100 tahun, Negara ini sudah memiliki generasi-generasi penduduk warga dunia yang bersifat transkultural, namun harus tetap hidup dan berkembang dalam jati diri dan budaya Indonesia sebagai sebuah bangsa yang bermartabat. Sesuai dengn prediksi pemerintah bahwa, generasi emas adalah dimana kondisi jumlah penduduk Indonesia diperkirakan 88 juta jiwa berusia 0-19 tahun lebih banyak dibandingkan usia tua.

\section{ANALISIS DAN SINTESIS \\ III.1. Analisis \\ III.1.1. Keterkaitan Pendidikan dengan Generasi Emas Indonesia}

Peran pendidikan dalam mempersiapkan generasi 2045 sangat penting. Target yang dicanangkan pemerintah berupa munculnya generasi emas Indonesia dalam sepuluh atau dua puluh tahun kedepan yang menurut Presiden Susilo Bambang Yudoyono yaitu dengan meluaskan kesempatan akses pendidikan lebih tinggi. Selain itu, dengan meningkatkan kualitas pendidikan sejalan dengan upaya meningkatkan kompetensi dan kesejahteraan guru.

Hal itu yang menyebabkan, Lembaga Pendidikan dan Tenaga Kependidikan (LPTK) perlu menyiapkan tenaga pendidik untuk menyiapkan generasi 2045 itu, dan manajemen ketenagaan pendidik yang profesional. Dalam konteks penyiapan generasi 2045, peran pendidik sangatlah penting dan masa depan bangsa ada di pundak pendidik atau guru.

Pendidikan merupakan hal yang sangat berpengaruh dalam mencapai generasi emas Indonesia di Tahun 2045 mendatang. Komponen-komponen seperti pemerintah, guru, dan siswa yang ada di dalam pendidikan harus saling mendukung satu sama lain, karena merekalah yang paling menentukan pendidikan seperti apa yang harus kita terapkan di
Indonesia untuk mencapai generasi emas tersebut.

Menyiapkan generasi 2045 sebagai generasi emas, Pemerintah dan perangkat pelaksana pendidikan tetap menjadikan proses pendidikan untuk semua (education for all) sebagai jalan utama dan menjadikan pekerjaan yang perlu dituntaskan. Sekaligus bukan hanya sekadar pemerataan, tetapi juga peningkatan kualitas. Mulai dari gerakan pendidikan anak usia dini, penuntasan dan peningkatan kualitas pendidikan dasar, penyiapan pendidikan menengah universal (PMU), dan perluasan akses ke perguruan tinggi juga disiapkan melalui pendirian perguruan tinggi negeri serta memberikan akses secara khusus kepada masyarakat yang memiliki keterbatasan kemampuan ekonomi untuk tetapi berkemampuan akademik untuk mendapatkan layanan pendidikan pada jenjang pendidikan yang lebih tinggi.

Dalam perguruan tinggi ada dua hal utama yang perlu mendapat prioritas penganggaran. Pertama, peningkatan mutu, aksesibilitas, relevansi, dan kesetaraan gender pada program S1, termasuk juga politeknik. Kedua, penambahan jumlah doktor. Ini penting karena lulusan pendidikan tinggi adalah tenaga ahli dan profesional yang siap memasuki dunia kerja (usaha dan industri) ataupun membuka lapangan kerja baru.

Menurut ketua umum DPP partai golkar pendidikan adalah sebuah martabat bangsa. Karena itu, jangan sampai ada keluarga yang putus sekolah atau tidak melanjutkan pendidikannya, akibat tidak mampu membayar biaya sekolah, tidak mampu membeli buku dan lain-lainnya. Bila hal itu sampai terjadi, maka itu berarti kita mengabaikan martabat bangsa. Ketua umum DPP partai golkar menegaskan kembali bahwa Pendidikan adalah kuncinya, karena pendidikan akan menghadirkan sumberdaya manusia yang andal. Seorang tokoh Samurai terkenal Jepang, Miyamoto Musashi mengatakan "The difference between the impossible and possible lies in a person's determination." Bahwa faktor keunggulan manusia dapat mengubah yang tidak mungkin menjadi mungkin. 
III.1.2. Usaha-Usaha Pemerintah Untuk Mencapai Generasi Emas Indonesia

Sistem Pendidikan yang Memungkinkan Dihasilkannya Pendidik dan Tenaga Kependidikan yang Kompeten untuk Mempersiapkan Generasi 2045", Prof. Sunaryo mengemukakan, investasi pendidikan adalah prediktor masa depan bangsa yang tercermin dalam mutu sumber daya manusia yang dihasilkan melalui upaya pendidikan itu. Modal dasar yang amat dahsyat di Indonesia adalah potensi jumlah penduduk produktif. Dalam kurun waktu 15-20 tahun mendatang diperkirakan lebih dari $60 \%$ penduduk Indonesia berada pada usia produktif (15-64 tahun). Potensi ini harus dikelola dengan tepat dan pendidikan adalah wahana paling strategis untuk mengelola potensi penduduk produktif.

Berkaitan dengan Hardiknas 2012 menarik sekali menyimak gagasan Mendikbud, Mohammad Nuh, yang disampaikannya pada konperensi pers seputar rencana perayaan Hardiknas Senin lalu (Pikiran Rakyat Online, 2 Mei 2012). Beliau menyatakan tahun ini sebagai Tahun Investasi untuk menanam 'generasi emas' Indonesia. Pemerintah telah menyiapkan grand design pendidikan untuk merealisasikan rencana besar Kemdikbud dalam mempersiapkan generasi emas 100 tahun Indonesia merdeka (2045).

Pendidikan anak usia dini digencarkan dengan gerakan PAUD-isasi, peningkatan kualitas PAUD, dan pendidikan dasar berkualitas dan merata. Selain itu, pembangunan sekolah/ruang kelas baru dan rehabilitasi bangunan tempat kegiatan belajar mengajar yang sudah tak layak akan dilakukan secara besar-besaran. Pada aspek pelajarnya, Pemerintah akan mengupayakan intervensi khusus untuk meningkatkan angka partisipasi kasar (APK) siswa SMA/sederajat. Nuh menambahkankan bahwa melalui upaya percepatan ini diharapkan APK SMA/sederajat dapat mencapai 97 persen pada 2020. Sementara bila tanpa intervensi persentase APK yang sedemikian diperkirakan baru tercapai pada 2040. Di sisi lain peningkatan APK perguruan tinggi juga dilakukan dengan meningkatan akses, memastikan keterjangkauan, dan memastikan ketersediaan.

Dengan kecenderungan pencapaian target seperti yang digambarkan, diharapkan pada tahun 2025 seluruh populasi anak usia dini memperoleh layanan pendidikan anak usia dini. Invenstasi PAUD harus mencakup infrastruktur dan ketenagaan, yang pada saat ini masih jauh dari standar yang diharapkan. Untuk mencapai harapan anak usia dini masa kini menjadi manusia Indonesia produktif pada 15 tahun yang akan datang maka PAUD tidak boleh diabaikan dan harus memperoleh prioritas pembiayaan.

Keseriusan pemerintah pun dibuktikan dengan adanya Rakornas Bidang Paud 2013 di Yogyakarta, yang dihadiri Kepala Dinas Dikpora DIY Kadarmanata Baskara, Ketua Divisi Tumbuh Kembang Pediatri Sosial Departemen Ilmu Kesehatan Anak FKUIRSCM Sujatmiko, dan Dekan Fakultas Psikologi Supra Wimbarti. Adapun Rakornas dihadiri oleh 350 peserta dari wilayah DIY dan perwakilan dinas pendidikan dari provinsi lainnya.

\section{III.2. Sintesis \\ III.2.1. Usaha-usaha untuk Mencapai Generesi Emas Indonesia}

Untuk mempersiapkan generasi emas Indonesia 2045, penting bagi dunia pendidikan melakukan perubahan pola pikir. Pendidikan tidak sekadar dimaknai dengan transfer akademik (keilmuan) saja, melainkan dilengkapi dengan karakter. Keseimbangan akademik dan karakter inilah yang perlu disiapkan sejak sekarang. Hal itu disampaikan Rektor IKIP PGRI Semarang Dr Muhdi SH MHum dalam diskusi ilmiah "Menyiapkan Pendidikan Generasi Emas Anak Bangsa untuk Mencapai Indonesia Emas" yang diselenggarakan Universitas Muria Kudus (UMK) di Auditorium Kampus, Senin (8/4).

Pemerintah selalu menuntut guru untuk bisa lebih kreatif, inovatif dan inspiratif dalam mendesain kegiatan pembelajaran yang bermutu untuk menyongsong generasi emas Indonesia. Jika memang guru menjadi kunci utama, seharusnya pemerintah meletakkan kekuasaan 
penuh terhadap guru untuk menyusun kurikulum serta mengevaluasi.

Untuk mencapai generasi emas Indonesia maka diperlukan juga Usaha meningkatkan mutu pendidikan di Indonesia seperti :

1. Meningkatkan Anggaran Pendidikan

Pemerintah bertanggung jawab untuk menanggung biaya pendidikan bagi warganya, baik untuk sekolah negeri maupun sekolah swasta.

2. Manajemen pengelolaan pendidikan

Manajemen pendidikan yang baik harus memperhatikan profesionalisme dan kreativitas lembaga penyelenggara pendidikan

3. Bebaskan sekolah dari suasana bisnis

Sekolah bukan merupakan ladang bisnis bagi pejabat Dinas Pendidikan, kepala sekolah, guru maupun perusahaan swasta. Tetapi sekolah merupakan tempat untuk mencerdaskan bangsa.

4. Perbaikan kurikulum

Pemerintah selalu menuntut guru untuk bisa lebih kreatif, inovatif dan inspiratif dalam mendesain kegiatan pembelajaran yang bermutu untuk menyongsong generasi emas Indonesia. Jika memang guru menjadi kunci utama, seharusnya pemerintah meletakkan kekuasaan penuh terhadap guru untuk menyusun kurikulum serta mengevaluasi. Penyusunan kurikulum hendaknya mempertimbangkan segala potensi alam, sumber daya manusia maupun sarana dan prasarana yang ada. Dan yang mengetahui segala bentuk kondisi di lapangan/di sekolah/di kelas-kelas hanyalah guru yang mengajar di kelas/di sekolah tersebut.

5. Pendidikan Agama

Pendidikan agama di sekolah bukan sebagai penyampaian dogma atau pengetahuan salah satu agama tertentu pada siswa tetapi sebagai penginternasionalisasian nilai-nilai kebaikan, kerendahan hati , cinta kasih dan sebagainya.

6. Pendidikan yang melatih kesadaran kritis

Sikap yang kritis dan toleran, akan merangsang tumbuhnya kepekaan sosial dan rasa keadilan. Oleh karena itu diharapkan bisa mengatasi kemelut sosial, budaya, politik dan ekonomi bangsa ini.

7. Pemberdayaan Guru

Berhubung Guru dituntut lebih kreatif, inovatif, terampil, berani berinisiatif serta memiliki sikap politik yang jelas. sebaiknya, pemerintah memberdayakan guru dengan program-program latihan sehingga mereka mampu mengembangkan model-model pengajaran secara variatif.

Selain itu, penulis juga berharap pemerintah Indonesia meniru kiat-kiat yang dilakukan oleh Negara-negara maju lainnya, misalnya Negara Finlandia. Seperti yang kita ketahui bahwa Negara Finlandia adalah Negara yang baik tata kelola pendidikannya, bahkan mengalahkan Amerika Serikat, Jepang, ataupun Jerman. Oleh sebab itu kiblat pendidikan dunia saat ini mengarah ke Negara Finlandia. Adapun Sistem pendidikan di Finlandia yaitu :

1. Anak-anak baru bersekolah saat usia 7 tahun

Anak-anak di Finlandia baru bersekolah saat usia 7 tahun, mereka tidak diperkenankan mengikuti playgroup ataupun sejenisnya. Pemerintah Finlandia justru memberi tugas kepada para orang tua untuk melaksanakan Pendidikan Anak Usia Dini. Alasannya karena dari bayi hinnga usia 6 tahun adalah masa yang kritis untuk tahap awal perkembangan anak. Pemerintah Finlandia memberi Maternity Package untuk setiap Ayah dan Ibu ketika ia memiliki bayi yang berisi panduan untuk mendidik anak mereka.

Bandingkan dengan para orang tua di Indonesia justru bangga anaknya sekolah pada usia 7 Tahun, bahkan pemerintah justru mencanangkan gerakan PAUD-nisasi menuju generasi emas Indonesia. Terus terang penulis kurang setuju dengan program pemerintah dengan mengutamakan PAUD sebagai titik tolak kita dalam "menanam bibit" generasi emas Indonesia.

2. Tidak ada tes hingga usia 16 tahun

Ketika anak-anak Finlandia masuk sekolah, tidak ada kewajiban untuk mengikuti ujian tingkat nasional, kecuali saat ia hendak melanjutkan kuliah di perguruan tinggi. Finlandia tidak menganut GERM (Global 
Education Reform Movement) yang menekankan pendidikan ke arah kompetisi dan persaingan. Pembelajaran di kelas pun berlangsung rileks tanpa ketegangan.

\section{Tidak banyak tugas dan PR}

Anak-anak Finlandia tidak perlu pulang ke rumah dengan membawa tugas yang tidak relevan dengan hobi dan kesenangannya. Mereka cukup mengembangkan bidang yang mereka sukai, menggali potensi dalam diri hingga bisa meraih prestasi. Mereka juga tidak perlu mengikuti bimbel ataupun mengerjakan puluhan soal di kelas. Satu kelas pun hanya berisi 15-17 siswa sehingga keadaan kelas lebih kondusif untuk belajar. Sehingga setiap siswa bisa berkonsultasi pada guru dengan leluasa.

4. Guru adalah tamatan S2 dengan lulusan terbaik

Di Finlandia, guru bukan hanya pahlawan tanpa tanda jasa tapi juga profesi terhormat. Bahkan orang Finlandia merasa lebih terhormat menjadi guru dibandingkan bekerja sebagai dokter. Untuk menjadi guru diperlukan kompetensi setara Strata 2 dengan nilai terbaik. Mereka wajib menerapkan metode belajar aktif dan menyenangkan serta memberi motivasi kepada para siswanya. Guru memiliki keintiman dengan siswanya maka guru pun bebas merumuskan kurikulum yang sesuai dengan karakteristik siswanya.

5. Tidak mengkotak-kotakan siswa dengan nilai prestasi atau tingkat ekonomi

Tidak ada mengkubu-kubukan siswa dengan penyebutan kelas reguler dan akselerasi apalagi VIP. Kualitas masing-masing sekolah tidak berbeda jauh sehingga tidak terlihat kesenjangan antar siswa. Para orang tua tidak perlu khawatir dengan biaya sekolah. Finlandia menanggung biaya pendidikan di sekolah hingga perguruan tinggi Strata 1 termasuk sekolah swasta. Kesempatan belajar dibuka lebar dan ditanggung pemerintah. Tidak perlu ada kekhawatiran tidak menerima ijazah karena belum membayar ataupun tekanan tidak naik kelas.

\section{III.2.2. Manfaat generasi emas Indonesia}

Dengan adanya generasi emas Indonesia maka diperoleh manfaat sebagai berikut :
1. Terbentuk generasi yang cerdas komprehensif, antara lain produktif, inovatif, damai dalam interaksi sosialnya, sehat dan menyehatkan dalam interaksi alamnya, dan berperadaban unggul.

2. Dapat mengangkat Indonesia menjadi negara maju dan merupakan kekuatan 12 besar dunia pada 2025 dan 8 besar dunia pada 2045 melalui pertumbuhan ekonomi tinggi yang inklusif dan berkelanjutan.

3. Indonesia diproyeksi menjadi salah satu dari 7 kekuatan ekonomi dunia dengan pendapatan perkapita USD 47.000. Saat ini pendapatan perkapita Indonesia mencapai USD 4.000.

4. Banyak pejabat menanggapi bahwa dengan tumbuhnya ekonomi yang besar di tahun 2045, Indonesia akan beralih status dari negara berkembang menuju negara maju.

5. Jika bonus demografi di tahun 2045 maka ekonomi kita tumbuh lebih dari sepuluh kali lipat dan Indonesia akan menjadi bagian dari negara maju.

6. Menjadikan Indonesia muda yang kreatif dan dinamis yang siap dan tegar untuk menghadapi peluang dan tantangan apapun juga

\section{KESIMPULAN DAN REKOMENDASI}

\section{IV.1. Kesimpulan}

Pendidikan merupakan wawasan yang diperoleh dari seorang pendidik untuk mengubah tingkah laku individu serta membimbing perkembangan jasmani dan rohani yang di didik untuk menuju yang lebih baik.

Generasi emas Indonesia yaitu generasi sekarang yang diberi bekal untuk generasi masa depan dalam menjadikan Indonesia menjadi Negara yang lebih maju. Untuk bisa mengiringi Negara maju lainnya maka kita perlu mempersiapkan generasi emas Indonesia dengan cara mengikuti atau melihat kiat-kiat yang di lakukan oleh Negara lain dalam dunia pendidikan mereka.

Pendidikan berkaitan erat dengan generasi emas idonesia karna pendidikan merupakan kunci untuk menghadirkan sumberdaya manusia yang andal dan dapat

\section{Diterbitkan Oleh Program Studi Pendidikan Informatika STKIP PGRI Sumbar}


mengubah sikap dan menambah ilmu seseorang.

\section{IV.2. Rekomendasi}

Pendidikan adalah sesuatu yang diperoleh oleh peserta didik yang dapat mengubah tingkah lakunya serta dapat memperluas wawasannya baik dalam segi jasmani maupun rohaninya. Maka dari itu pendidikan harus diperoleh seseorang untuk menjadikan individu yang cerdas yang dapat berguna bagi bangsa dan Negara. Jadi marilah kita sama-sama berusaha untuk mendapatkan pendidikan yang lebih supaya tidak tertinggal oleh Negara-negara maju.

\section{DAFTAR PUSTAKA}

B. Johnson Elanie. 2008. Brain-Based Learning. Del Mar, CA: Turning Point Publishing
Ella Yulaelawati. 2004. Kurikulum dan Pembelajaran. Bandung : Pakar Raya

Hikmawati. 2013. Pendidikan dan Generasi Emas Indonesia. (online), (http://tambingkaran.blogspot.com, diakses 29 Maret 2014).

Muhamad Yusuf. 2013. Guru, Mutiara Pendidikan untuk Generasi Emas Indonesia Tahun 2045. (online), (http://madyusuf.wordpress.com, diakses 29 Maret 2014).

Muhamad Yusuf. 2014. Mengapa Finlandia Memiliki Sistem Pendidikan Terbaik di Dunia. (online), (http://madyusuf.wordpress.com, diakses 29 Maret 2014).

Mulyasa. 2008. Menjadi Guru Profesional: Menciptakan Pembelajaran Kreatif dan Menyenangkan. Bandung: Rosda Karya. 